\title{
Ideal Free Distributions of Mobile Pastoralists in Multiple Seasonal Grazing Areas
}

Author(s): Mark Moritz, Ian M. Hamilton, Paul Scholte, and Yu-Jen Chen

Source: Rangeland Ecology \& Management, 67(6):641-649. 2014.

Published By: Society for Range Management

DOI: http://dx.doi.org/10.2111/REM-D-14-00051.1

URL: http://www.bioone.org/doi/full/10.2111/REM-D-14-00051.1

BioOne (www.bioone.org) is a nonprofit, online aggregation of core research in the biological, ecological, and environmental sciences. BioOne provides a sustainable online platform for over 170 journals and books published by nonprofit societies, associations, museums, institutions, and presses.

Your use of this PDF, the BioOne Web site, and all posted and associated content indicates your acceptance of BioOne's Terms of Use, available at www.bioone.org/page/terms_of_use.

Usage of BioOne content is strictly limited to personal, educational, and non-commercial use. Commercial inquiries or rights and permissions requests should be directed to the individual publisher as copyright holder. 


\title{
Ideal Free Distributions of Mobile Pastoralists in Multiple Seasonal Grazing Areas
}

\author{
Mark Moritz, ${ }^{1}$ Ian M. Hamilton, ${ }^{2}$ Paul Scholte, ${ }^{3}$ and Yu-Jen Chen ${ }^{4}$
}

Authors are ${ }^{1}$ Associate Professor, Department of Anthropology, and ${ }^{2}$ Associate Professor, Departments of Evolution, Ecology and Organismal Biology and Mathematics, and ${ }^{4}$ Graduate Student, City and Regional Planning, Obio State University, Columbus, OH 43210, USA; and ${ }^{3}$ Program Coordinator, Sustainable Forest Management in the Congo Basin, German Development Organization (GTZ), Yaoundé, Cameroon.

\begin{abstract}
The pastoral system in the Far North Region of Cameroon is best described as an open system in which mobile pastoralists have open access to common-pool grazing resources. We hypothesized that there is a self-organizing management system of open access to common-pool grazing resources and predicted that we would find an Ideal Free Distribution (IFD) of mobile pastoralists within seasonal grazing areas. In this paper we used mobility data and remote sensing data from two seasonal grazing areas at the end of the dry season in three consecutive years to evaluate that hypothesis. We found evidence of an IFD in the two seasonal grazing areas of the Logone Floodplain and the Lake Maga area. These findings offer further support for our hypothesis that there is a complex adaptive system in which pastoralists distribute themselves effectively over available grazing resources.
\end{abstract}

Key Words: behavioral ecology, common-pool resources; complex adaptive system, Ideal Free Distribution, pastoral systems

\section{INTRODUCTION}

The pastoral system in the Logone Floodplain in the Far North Region of Cameroon is best described as an open system in which mobile pastoralists have open access to common-pool grazing resources (Moritz et al. 2013b). Every year thousands of pastoralists from different ethnic groups from Niger, Nigeria, and Cameroon move into the floodplain with more than 200000 cattle to spend a considerable part of the dry season. We have found that pastoralists adjust the grazing pressure to the available grazing resources in the floodplain, no major conflicts among pastoralists, and no evidence of a tragedy of the commons (Scholte et al. 2006).

We have argued that this pastoral system is best understood as a complex adaptive system, which is "a system in which large networks of components with no central control and simple rules of operation give rise to complex collective behavior, sophisticated information processing, and adaptation via learning or evolution" (Mitchell 2009). Examples of complex adaptive systems are ant colonies (Gordon 2010), immune systems (Mitchell 2009), and irrigation systems (Lansing 2006).

In the case of the pastoral system in the Far North Region, there are no rules among mobile pastoralists regulating access to common-pool grazing resources and no collective and/or centralized decision making about movements and campsite selection. Instead, individual pastoralists (components) make their own independent and autonomous decisions about where to move, set up their camps, and graze their animals (rules of

\footnotetext{
Research was funded by the National Science Foundation (BCS-0748594), the National Geographic Society (8306-07), and the College of Social and Behavioral Sciences and the Department of Anthropology at Ohio State University.

Correspondence: Mark Moritz, Dept of Anthropology, Ohio State University, 175 W 18th Avenue, Columbus, OH 43210, USA. Email: moritz.42@osu.edu
}

Manuscript received 6 April 2014; manuscript accepted 25 June 2014.

(c) 2014 The Society for Range Management operation). In their decision making pastoralists consider both the distribution of resources and other pastoralists (information processing) and are coordinating their movements with other pastoralists (adaptation). This coordination occurs in a dynamic environment in which processes of grazing, burning, and desiccation continually change the distribution of resources and, through a self-organizing process, the distribution of pastoralists.

We have argued that in this complex adaptive system of open access to common-pool grazing resources we would find evidence of an Ideal Free Distribution (IFD), characterized by a positive correlation between use of camp zones by herds and available grazing resources within camp zones, in multiple seasonal grazing areas within the larger Chad Basin (Moritz et al. 2013b). In an earlier study we found support for an IFD of mobile pastoralists within the Logone Floodplain, Cameroon, at the beginning of the dry season (Moritz et al. 2014). However, questions have been raised about whether the Logone Floodplain is a unique case and to what extent our findings apply to other grazing areas. Here we use data from the Logone Floodplain (Yaayre) and the Lake Maga area (Ndiyam Shinwa) at the end of the dry season in three consecutive years (20102012) to examine whether there is an IFD within multiple seasonal grazing areas. We have selected these two areas because they are two of the most important grazing areas in the dry season for mobile pastoralists in the Far North Region.

The IFD model predicts how animals should distribute themselves over resource patches or habitats (Fretwell and Lucas 1969; Sutherland 1996). The two main assumptions in the IFD model are 1) individuals have perfect knowledge about the resource quality and quantity of each patch (ideal assumption) and 2) individuals are free to move to any patch (free assumption). When those conditions are met, the theory predicts that individuals should be distributed such that no individual can gain more resources by moving to a different patch. Quantitative predictions of ideal free models depend on the assumptions specific to each model. However, we can make 
three general predictions about IFDs when resources deplete slowly. First, use of a patch should be positively correlated with the total resources available in the patch (which is a function of resource density and patch area). Second, if not all patches are occupied, then occupied patches should have higher resource availability than unoccupied patches. Third, the variance in standing resource quality of occupied habitats should be lower than the variance in resource quality of unoccupied habitats, because herds will tend to deplete all occupied habitats to the same quality, while, in unoccupied habitats, current resource quality is unaffected by depletion.

The concept of the IFD has been used in behavioral ecology studies to examine habitat selection and foraging strategies of animals (Kennedy and Gray 1993; Sutherland 1996; Hamilton 2010), but recently it has also been used to study the mobility and settlement patterns of human populations (Kennett et al. 2006; Winterhalder et al. 2010), including mobile pastoralists (Scholte et al. 2006; Behnke et al. 2008, 2011). Pastoral systems provide an excellent case for examining IFD theory because the mobility and settlement patterns of pastoralists are primarily driven by spatiotemporal changes in the distribution of forage and water, even though the human dimension of pastoral systems means that nonforage constraints shape mobility and settlement patterns (Behnke et al. 2011).

Although pastoralists are likely neither perfectly ideal nor perfectly free to move, the pastoral system in the Far North Region does closely match these two main assumptions of the IFD. First, while pastoralists do not have perfect information, they have reliable information about the suitability of different habitats through a combination of scouting and information sharing within social networks. Second, access to commonpool grazing resources is best described as open access in that there are no regulations restricting access, which means that pastoralists are free to move to any habitat.

However, the pastoral system does not fit all of the assumptions of ideal free models (for a detailed discussion see Moritz et al. 2014). For example, pastoralists do not necessarily have similar preferences and assessment of habitats; their annual transhumance shapes and is shaped by habitual preferences for habitats on these orbits, so while they may be free to move, habitual preferences may influence the decision to move. Also, travel times between habitats are non-negligible. It may take herds $2 \mathrm{~d}$ to get from one end of the floodplain to another. Moreover, during these movements animals expend energy and have less time to graze (which they make partially make up by grazing longer at night during movement days). These and other challenges notwithstanding, we think that the IFD is an appropriate model to describe and explain habitat selection of mobile pastoralists within season grazing areas (Moritz et al. 2014).

Because pastoralists use mobility to exploit spatiotemporal variation in forage availability, they are continuously moving in response to ever changing distributions of common-pool grazing resources. One can examine pastoral mobility and distributions at multiple spatiotemporal scales ranging from daily herd movements (Butt 2009; Moritz et al. 2010; Moritz et al. 2012) to annual transhumance movements (Schareika 2003; Behnke et al. 2008) to decadal migratory drift (Stenning 1957; Boutrais 1996; Bassett and Turner 2007). We expect to find support for the predictions of the ideal free model at multiple spatiotemporal scales, when mobile pastoralists with complete information, freedom and ability to move, and independent and individual decision-making capabilities have open access to depletable common-pool grazing resources that are highly variable in space and time.

\section{STUDY AREA AND POPULATION}

Two phytogeographic zones characterize the Far North Region of Cameroon: Sudanian in the southern grades and Sahelian in the Logone Floodplain (Yaayre). The Logone Floodplain is flooded by the Logone River and its branches from September until November. After the water recedes in December, thousands of Arab and FulBe pastoralists from Cameroon, Nigeria, and Niger move with more than 200000 cattle into the floodplain, making it one of the most important dry season grazing lands in the Lake Chad Basin (Seignobos and IyébiMandjek 2000). Many remain there until the start of the rainy season in June, while others move to the floodplain further north (Yaayre Woylare), the floodplain in Chad (Mayo Bori), or the lakeside pastures around Lake Maga (Ndiyam Shinwa) (Fig. 1). Mobile pastoralists find nutritious regrowth and surface water in the Logone Floodplain and around Lake Maga far into the dry season, when surrounding pastures have dried up. At the start of the rainy season, pastoralists return to Diamare plains or their respective countries.

The vegetation in the Logone Floodplain is relatively homogenous in terms of forage quantity and quality because of the extreme flatness of the area resulting in only limited variation in flooding depth and duration (Scholte 2007). There is only weak coupling between herbivores and vegetation as the predominantly perennial vegetation is controlled by flooding depth and duration and naturally protected against overgrazing because up to two-thirds of the biomass is stored underground. In addition above ground biomass is generally inaccessible to livestock during the 6 mo of the rainy and flooding seasons (Scholte 2007).

The lakeside pastures around Lake Maga were created in 1979 when the Cameroonian government constructed dikes along the Logone River and a dam between Guirvidig and Pouss to create a $400-\mathrm{km}^{2}$ reservoir, Lake Maga, for the irrigated rice cultivation project SEMRY II (Delclaux et al. 2010). The dam led to a significant reduction in flooding and regime shifts in the Logone Floodplain (Scholte 2005). However, the anthropogenic pastures around Lake Maga have now become a critical part of the mobile pastoralist system and are used by approximately 100000 cattle at some point during the year.

The vegetation around Lake Maga is also relatively homogenous in terms of forage quantity and quality. But while the area is also extreme flat, the flooding dynamics in this anthropogenic floodplain are very different from those in the Logone Floodplain. The main hydrological difference is the duration of the flooding. In the Logone Floodplain the floods recede completely after about 5 mo (Jung et al. 2011), whereas the flooding in the Lake Maga pastures is controlled primarily by SEMRY II when it releases water for irrigating the rice fields. As a result, the water recedes very slowly, and the pastures in Lake Maga are flooded for a much longer period. 


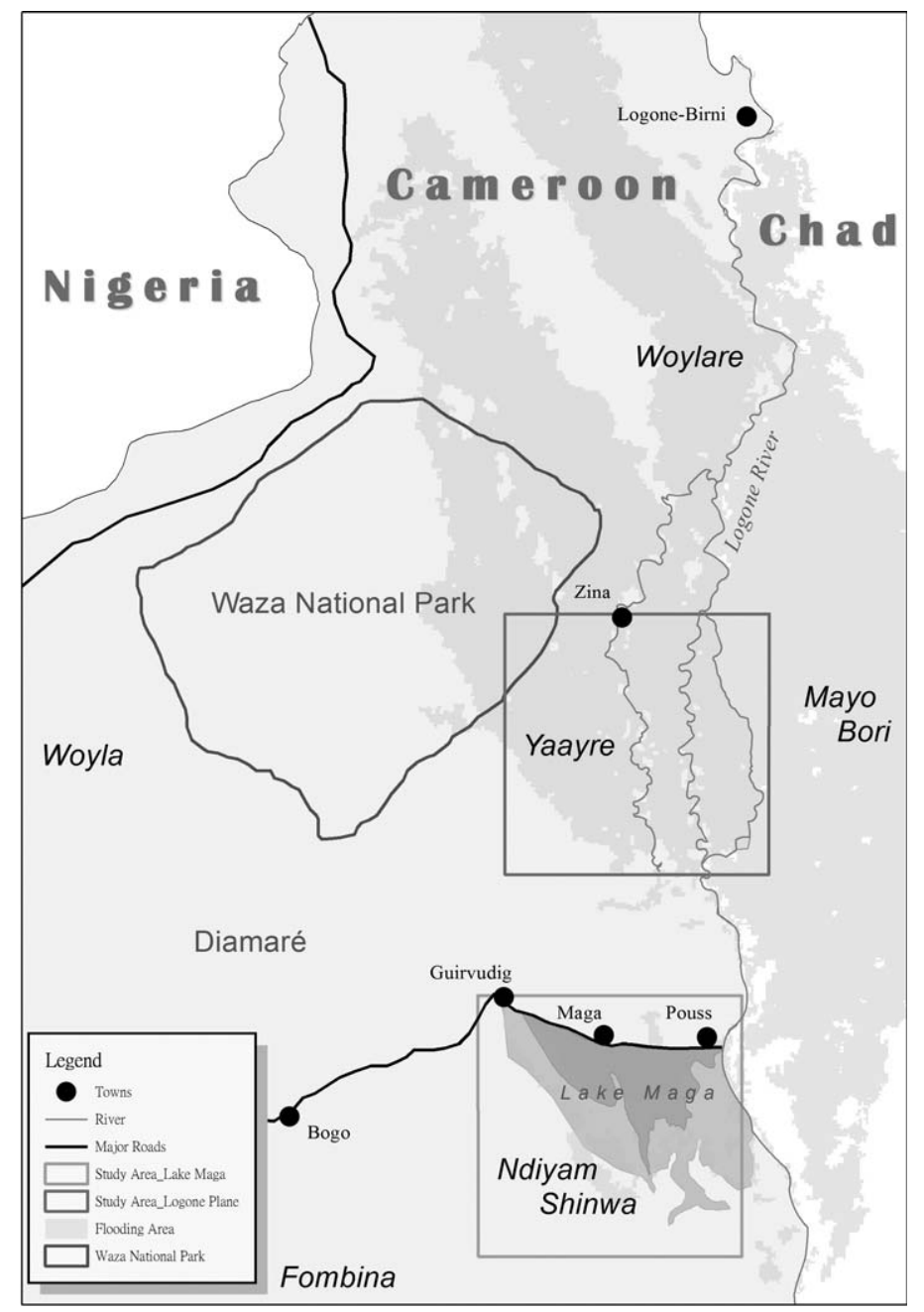

Figure 1. Study areas in the Far North Region of Cameroon. The dry season grazing areas in the Logone Floodplain and the Lake Maga area are part of the mobile pastoral system in the Chad Basin that also includes other seasonal grazing areas in Chad, Niger, Nigeria, and Cameroon.

The study population consists of all mobile pastoralists who use the Logone Floodplain (Yaayre) at some point during the year. Many of them use the floodplain during the cold dry season in November and December when the water retreats and then either leave for the floodplain farther north (Yaayre Woylare), the floodplain in Chad (Mayo Bori), or the lakeshore pastures of Lake Maga in the south (Ndiyam Shinwa). The population consists of approximately 1200 households divided over approximately 150 camps and includes Suwa Arabs and FulBe, which are subdivided into Jamaare, Mare, Alijam, Adanko, and Anagamba groups. These different FulBe groups are endogamous and have their own dialect, cattle breed, houses, and marriage system.

Pastoralists set up their camps in koodaande (singular hoodaande), which refer to sites, i.e., the location of herds and households, as well as the larger area in which these sites are located. We refer to the former as campsites and the latter as camp zones. In the floodplain, campsites are often located in depressions for easy access to water for humans and calves and protection from bush fires. They are also located close to the three rivers that intersect the floodplain in the east or close to the artificial lakes in the west that were dug by the Lake Chad Basin Commission (LCBC). Some camp zones are places where pastoralists stay for an extended period (sojourn), up to $6 \mathrm{mo}$, while in other zones they stay for only a few days (transit). Different pastoralists may use the same camp zones for either transit or sojourn.

\section{METHODS}

Data for this article were collected in longitudinal study of pastoral mobility in the Far North Region of Cameroon. We used a combination of spatial and ethnographic approaches to describe and explain the distribution of mobile pastoralists in our study areas in the Logone Floodplain and the Lake Maga area in three successive years, 2010-2012. The seasonal grazing areas in the Logone Floodplain and the Lake Maga area are part of a larger pastoral ecosystem in the Chad Basin in which mobile pastoralists move between different rainy and dry season grazing areas.

To document the distribution of mobile pastoralists we used GPS/GIS technology to map the locations of all pastoralists' camps in the two areas at the end of the dry season (May). During these visits, we identified all the households in the camp, the number of herds, and the name of the campsite. We also conducted an annual transhumance survey each August in which we asked pastoralists the names and number of days of all the sites they had stayed in the previous year. The transhumance data helped us understand how the use of the Logone Floodplain and Lake Maga area fits in with the larger annual transhumance movements. In addition, we used a combination of participant observation and informal, semistructured, and structured interviews to understand how pastoralists use common-pool grazing resources, including campsite selection and decisions about movements.

To estimate the distribution of the available resources in the floodplain we used remote sensing data, in particular the Normalized Difference Vegetation Index (NDVI), which is an indicator of the quality and quantity of forage. NDVI is one of the most common remote sensed vegetation indices for measuring plant growth and vegetation cover (Anyamba and Tucker 2005), including in the assessment of pastoral ecosystems (Coughenour et al. 2008; Butt 2010). It uses the spectral characteristics of different features such as vegetation, soil, and water in the red and near-infrared band regions to evaluate the condition of vegetation on the ground. The value of NDVI varies from -1 to +1 due to the reflective properties of different kinds of surface. Typically the range for vegetation is between 0.1 and 1.0; the value close to 1.0 means a higher density of green vegetation (Lillesand et al. 2007). We used MODIS MOD13A2 satellite data, which are collected every 16 $\mathrm{d}$ at $1-\mathrm{km}$ resolution, to calculate the NDVI values for our study areas. While NDVI is not a reliable index for absolute measurements of vegetation, it is very useful as a relative measure of green biomass in the same area at the same time (Anyamba and Tucker 2005).

Using ArcGIS software, we divided up our study areas in a grid with $1-\mathrm{km}^{2}$ cells and calculated the NDVI value for all $1-\mathrm{km}^{2}$ cells in the study areas for the month of May. The grid of the Lake Maga area $(20 \times 30 \mathrm{~km})$ is smaller that that of the Logone 
Floodplain $(30 \times 30 \mathrm{~km})$ because the grazing area around the lake is smaller. We calculated the NDVI for the camp zones by creating buffers with a $1.5-\mathrm{km}$ radius around each campsite (using the GPS coordinates from our surveys). We combined the buffers that overlapped and had the same toponym into one larger buffer (e.g., all the buffers from the Cubuna campsites were combined into one Cubuna camp zone buffer).

We used a combination of statistical analyses to test the whether the distributions of mobile pastoralists were consistent with the predictions of the IFD in the two grazing areas (using GraphPad InStat version 3.0a and SPSS version 19 for Macintosh). First, we used descriptive statistics, $t$ tests, and ANOVA to describe and compare the NDVI values for the study areas, as well as the occupied and unoccupied cells in the different years. Second, we used descriptive statistics to describe the population of mobile pastoralists for the different years (2010-2012). Third, we used correlations and multiple regressions to examine whether there is a correlation between the NDVI and the number of cattle for the camp zones in each year. We also calculated for each camp zone the percentage of the NDVI and of cattle (as a percentage of all the camp zones combined for each year) to examine whether there was underuse or overuse of habitats and whether there was a correlation between the properties of each camp zone (e.g., NDVI, number of cattle) and under- or overuse.

\section{RESULTS}

Here we will describe the results from our study. First, we describe patterns in NDVI and the pastoral population. Second, we will discuss correlations between the NDVI and grazing pressure for 3 yr (2010-2012) within the seasonal grazing areas of the Logone Floodplain (LF) and the Lake Maga (LM) area.

\section{NDVI in the Seasonal Grazing Areas}

Pastoral mobility is driven by seasonal variations in rainfall, which results in spatiotemporal variation in pastoral resources: forage and water. FulBe pastoralists in the Far North Region talk about four distinct seasons when they discuss their mobility patterns. The rainy season (duumol) runs from July through September with the biggest rains in July and August. It is followed by the cold dry season, (daBBunde) from October to January and the hot dry season $($ ceedu) from February to May. June is a transition season (seeto) from dry to rainy season.

The seasonal dynamics drive the movements of mobile pastoralists who leave the rainy season grazing areas (ruumirde) at the beginning of October and enter the Logone Floodplain by November, where they spend the cold dry season. By February they have settled in their dry season campsites (ceedirde) in the Yaayre, Yaayre Woylare, Mayo Bori, or Ndiyam Shinwa. In June they start following the rain clouds and then slowly return to their rainy season grazing areas.

The change in NDVI values in the LF and the LM area capture well the seasonal dynamics described above (Fig. 2). However, there are clear differences in the dynamics between the two areas: first, NDVI values reach higher peaks in LF (0.7$0.8)$ versus LM (0.6) in the rainy season; second, NDVI values decrease later but faster in LF than in LM in the cold dry season; third, NDVI values are lower in LF (0.2) than in LM $(0.25)$ in the hot dry season; fourth, NDVI values increase later but faster in LF than in LM in the rainy season.

These differences are in line with our observations that most pastoralists leave the LF for the LM area in the hot dry season. In May the NDVI values in the LM area are significantly higher than in the LF in the $3 \mathrm{yr}$ (Kruskal-Wallis test, $P<0.001$ ) and that is also true when we compare only the occupied cells (Kruskal-Wallis test, $P<0.001$ ).

\section{Changes in Pastoral Populations in the Seasonal Grazing Areas}

Compared to the LF, there are consistently more mobile pastoralists and more cattle in the LM area in May in all 3 yr (Table 1). The number of cattle fluctuates considerably from

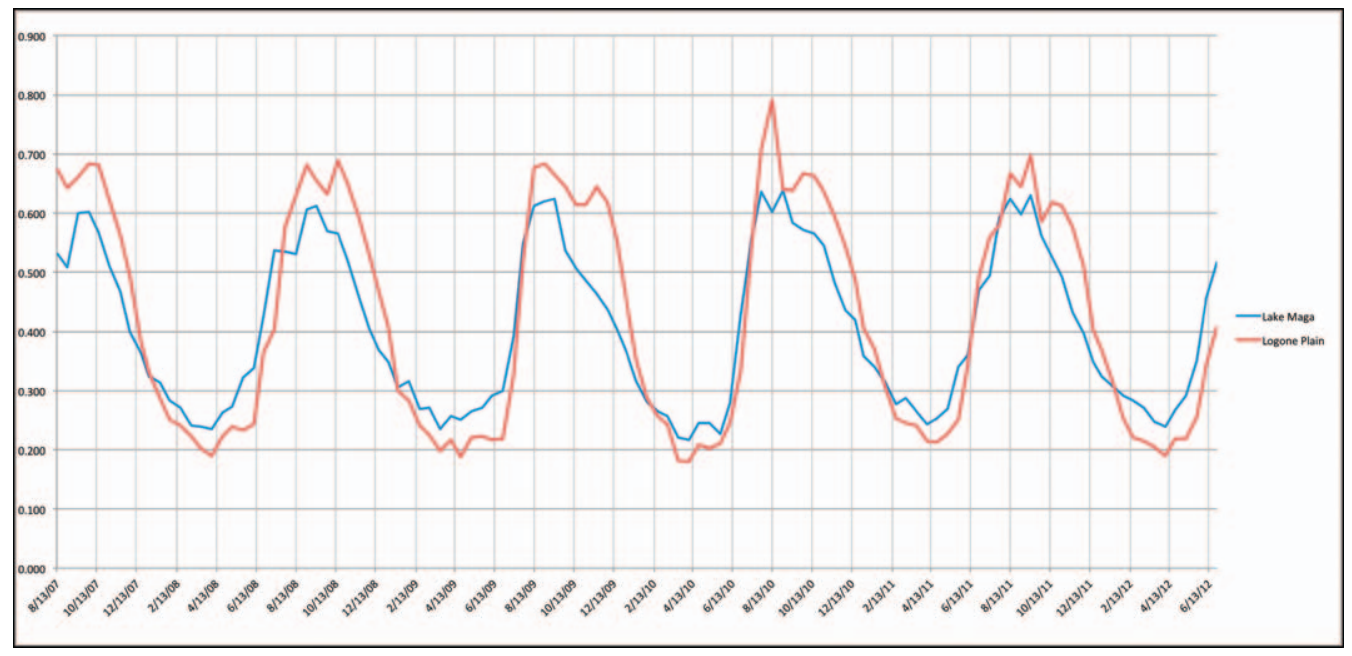

Figure 2. Average NDVI values in the study areas, 2007-2012. The red (light) line shows the NDVI values in the Logone Floodplain. The blue (dark) line shows the NDVI values in the Lake Maga area. The Logone Floodplain has higher values earlier in the dry season, while the Lake Maga area has higher values later in the dry season. This is also reflected in the distribution of mobile pastoralists in these two areas. Many pastoralists move from the Logone Floodplain to the Lake Maga area in the middle of the dry season. 
Table 1. Population of mobile pastoralists in the two study areas in May 2010-2012.

\begin{tabular}{|c|c|c|c|c|c|c|c|c|c|c|}
\hline & \multicolumn{2}{|c|}{ No. of camps } & \multicolumn{2}{|c|}{ No. of households } & \multicolumn{2}{|c|}{ No. of cattle } & \multicolumn{2}{|c|}{ Households per camp } & \multicolumn{2}{|c|}{ Cattle per camp } \\
\hline & LF & LM & LF & LM & LF & LM & LF & LM & LF & LM \\
\hline 2010 & 32 & 73 & 324 & 447 & 32310 & 37905 & 10 & 6 & 1010 & 519 \\
\hline 2011 & 30 & 50 & 187 & 290 & 16285 & 26385 & 6 & 6 & 543 & 528 \\
\hline 2012 & 28 & 58 & 263 & 292 & 23480 & 26995 & 9 & 5 & 839 & 465 \\
\hline Average & 30 & 60 & 258 & 343 & 24025 & 30428 & 9 & 6 & 797 & 504 \\
\hline
\end{tabular}

year to year in both areas (by more than 15000 in the LF and more than 10000 in the LM area).

The population of mobile pastoralists within the seasonal grazing areas changes over the course of the dry season, and we found that there are fewer cattle in the LF in May than in February on average (24025 vs. 28810 cattle, respectively). (We do not have data for the population of mobile pastoralists in the LM area in February.) In May a number of pastoralists from the Yaayre and Yaayre Woylare anticipate the rains and start moving south to the LM area. It is important to keep in mind that the distribution of mobile pastoralists is continuously in flux as they are responding to spatiotemporal variation in forage availability.

\section{Matching NDVI and Animal Numbers Within Seasonal Grazing Areas}

We have found support for one of the predictions for the distributions of mobile pastoralists within both the LF and the LM area. There were significant linear correlations between the NDVI values and number of animals in camp zone buffers within the LF in 2 of the $3 \mathrm{yr}$ and in the LM area in all $3 \mathrm{yr}$ (Table 2). We did not find a significant correlation in the LF in 2011 , although with the removal of one outlier it is significant $(r=0.7629, n=13, P=0.0024)$. In an earlier study we found no significant correlations between total NDVI and number of animals in camp zone buffers in the LF in February 2010 and 2011 (Moritz et al. 2014). We have argued that this is because of insecurity problems in which pastoralists were terrorized by bandits who were kidnapping children for a ransom (Moritz and Scholte 2011; Moritz et al. 2014). Insecurity may also have affected the distribution of pastoralists in May 2010 and 2011.

Table 2. Linear correlations between NDVI and number of animals in camp zones buffers within the Logone Floodplain and the Lake Maga area in May 2010-2012.

\begin{tabular}{|c|c|c|c|}
\hline & $r$ & $N$ & $P^{1}$ \\
\hline \multicolumn{4}{|c|}{ Logone Floodplain } \\
\hline 2010 & 0.6171 & 12 & *0.0325 \\
\hline 2011 & 0.4912 & 14 & 0.0739 \\
\hline 2012 & 0.8171 & 13 & $* * 0.0006$ \\
\hline \multicolumn{4}{|c|}{ Lake Maga area } \\
\hline 2010 & 0.8031 & 14 & **0.0005 \\
\hline 2011 & 0.8671 & 11 & $* * 0.0005$ \\
\hline 2012 & 0.7405 & 12 & $\star * 0.0059$ \\
\hline
\end{tabular}

\section{Comparison of Resource Availability in Occupied and Unoccupied Zones}

We also found support for the second prediction that occupied cells should have higher resource availability than unoccupied cells (Table 3), except for the LF in 2010 when NDVI values were low throughout the area. In addition, we found support for the third prediction in that the variance in NDVI values of occupied cells was lower than the variance in unoccupied cells in the LM area, but not in the LF (Table 4).

\section{Differences in Daily Herd Movements Between the Two Seasonal Grazing Areas}

The seasonal grazing areas of the LF and the LM area are qualitatively different. We have shown already that the average NDVI values are significantly higher in the LM area in May. The maps also show that the NDVI values near the shores of the LM area are higher than those in grazing lands farther away from the lake due to the slow retreat of the water (Fig. 3). This is also reflected in the daily movements of herds, which spend most of their time grazing in the flooded pastures.

Herds in the LM area graze more intensively, cover less distance, and travel less far from the campsite than in the LF (Table 5). Although our sample is small for the LM area $(N=5)$, there are significant differences in the daily herd movements between the two areas in terms of mean speed (Mann-Whitney Test, $U=22, P=0.0357$ ), total distance (Mann-Whitney Test, $U=22, P=0.0326$ ), and herding radius (Mann-Whitney Test, $U=16, P=0.0104)$. Despite the higher NDVI values, shorter travel times, and more intensive grazing in the LM area, pastoralists comment that the condition of cattle in the LM area is not necessarily better than in the LF. They have noted that cattle have lower reproductive rates,

Table 3. Results from Mann-Whitney test comparing NDVI values of occupied and unoccupied cells in May 2010-2012.

\begin{tabular}{ccccr}
\hline & $\begin{array}{c}\text { Occupied } \\
\text { mean }\end{array}$ & $\begin{array}{c}\text { Unoccupied } \\
\text { mean }\end{array}$ & $\begin{array}{c}\text { Mann-Whitney } \\
U \text { statistic }\end{array}$ & $P$ value \\
\hline \multicolumn{2}{l}{ Logone Floodplain } \\
2010 & 0.2084 & 0.2090 & 56582 & 0.2899 \\
2011 & 0.2623 & 0.2557 & 48120 & $* * 0.0005$ \\
2012 & 0.2621 & 0.2568 & 49740 & $* * 0.0039$ \\
Lake Maga area & & & \\
2010 & 0.2605 & 0.2388 & 35263 & $* * 0.0039$ \\
2011 & 0.3352 & 0.2911 & 26251 & $* *<0.0001$ \\
2012 & 0.3692 & 0.3289 & 26082 & $* *<0.0001$ \\
\hline $1 * *$
\end{tabular}

$1 \star \star$ is significant at the $1 \%$ level. 
Table 4. Results from F test for variances in NDVI values of occupied and unoccupied cells in May 2010-2012.

\begin{tabular}{|c|c|c|c|c|c|c|}
\hline & \multicolumn{2}{|c|}{ Variance } & \multirow[b]{2}{*}{$\mathrm{F}$} & \multicolumn{2}{|c|}{ df } & \multirow[b]{2}{*}{$P$} \\
\hline & Occupied & Unoccupied & & Numerator & Denominator & \\
\hline \multicolumn{7}{|c|}{ Logone Floodplain } \\
\hline 2010 & 0.00038 & 0.00041 & 1.082 & 592 & 195 & 0.5149 \\
\hline 2011 & 0.00081 & 0.00095 & 1.176 & 597 & 190 & 0.1828 \\
\hline 2012 & 0.00070 & 0.00077 & 1.107 & 593 & 193 & 0.4021 \\
\hline \multicolumn{7}{|c|}{ Lake Maga area } \\
\hline 2010 & 0.00235 & 0.00685 & 2.916 & 350 & 230 & $* *<0.0001$ \\
\hline 2011 & 0.00465 & 0.01061 & 2.283 & 397 & 192 & $\star *<0.0001$ \\
\hline 2012 & 0.00403 & 0.01171 & 2.291 & 410 & 166 & $\star *<0.0001$ \\
\hline
\end{tabular}

$1 * \star$ is significant at the $1 \%$ level.

lower milk production, and higher calf mortality than in natural floodplains, and they explain these effects in terms of lower forage quality and higher parasite loads. However, there have yet been no studies to examine these claims.

We also compared cattle numbers and NDVI values between the two seasonal grazing areas and found, as predicted, consistently more cattle in the LM area than in the LF (Table 6). However, there is overuse in the LF and underuse in the LM area, meaning there are proportionally more cattle than resources in the LF and fewer cattle than resources in the LM area. In addition, we find the ratios of cattle (LM:LF) are not correlated with the ratios of NDVI (LM:LF); e.g., we would expect the ratio of cattle in LM:LF to be lower in 2011, but it is higher. In sum, at this point there is no evidence to support an IFD between seasonal grazing areas.

\section{DISCUSSION}

In a study of pastoral mobility in the Far North Region of Cameroon we found additional support that mobile pastoralists are distributing themselves in an ideal free-like distribution. We found support for the predictions of a depletion model of the IFD within each of the two seasonal grazing areas. First, we found statistically significant correlations between the number of cattle and NDVI (except for 2011 in the Logone Floodplain). Second, we found statistically significant higher NDVI values in occupied cells than in unoccupied cells (except for 2010 in the Logone Floodplain). Third, we found statistically significant greater variance in NDVI values in unoccupied cells compared to occupied cells at Lake Maga, but not in the Logone Floodplain.

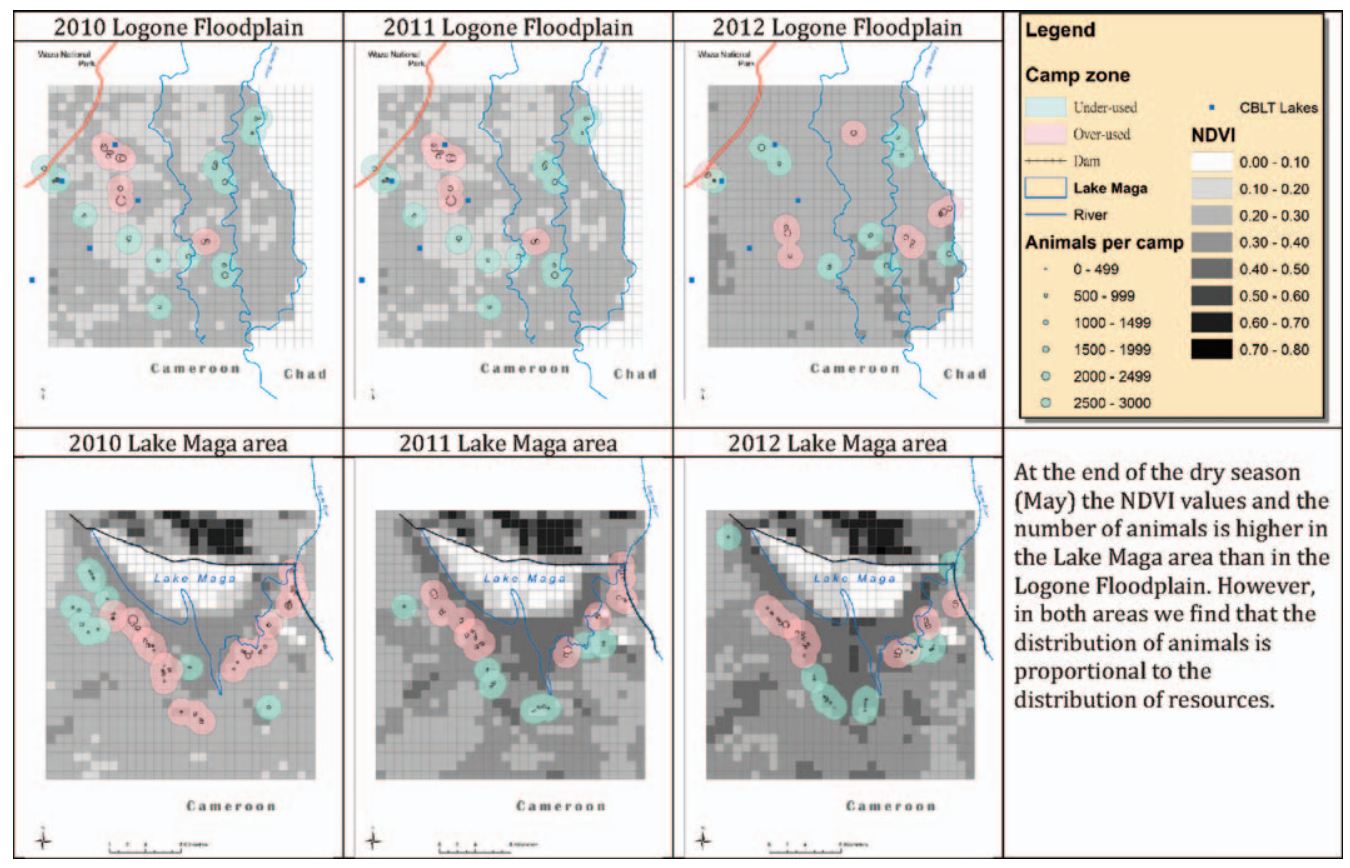

Figure 3. Distribution of mobile pastoralists in the study areas in May 2010-2012. At the end of the dry season (May) the NDVI values and the number of animals is higher in the Lake Maga area than in the Logone Floodplain. However, in both areas we find that the distribution of animals is proportional to the distribution of resources. 
Table 5. Descriptive statistics for daily herd movements in Logone Floodplain (LF) $(N=23)$ and Lake Maga area $(L M)(N=5){ }^{1}$

\begin{tabular}{|c|c|c|c|c|c|c|c|c|}
\hline & \multicolumn{2}{|c|}{ Herding radius $(\mathrm{m})$} & \multicolumn{2}{|c|}{ Total distance (m) } & \multicolumn{2}{|c|}{ Mean speed (km/h) } & \multicolumn{2}{|c|}{ Total herding time } \\
\hline & LF & LM & LF & LM & LF & LM & LF & LM \\
\hline Mean & 4427 & 2675 & 14898 & 11469 & 2.28 & 2.02 & $11: 10$ & $11: 08$ \\
\hline Minimum & 2190 & 2296 & 9726 & 8689 & 1.92 & 1.64 & $10: 11$ & $10: 51$ \\
\hline Maximum & 7564 & 3897 & 20511 & 17120 & 2.60 & 2.17 & $12: 26$ & $11: 30$ \\
\hline
\end{tabular}

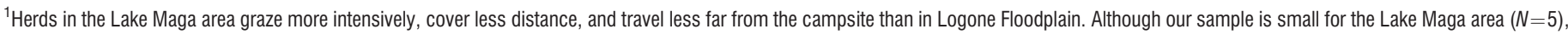
there are significant differences in the daily herd movements between the two areas in terms of mean speed (Mann-Whitney test, $U=22, P=0.0357$ ), total distance (Mann-Whitney test, $U=22$, $P=0.0326$ ), and herding radius (Mann-Whitney test, $U=16, P=0.0104$ ). There are no significant differences in total herding time.

Earlier we found evidence of an ideal free-like distribution in the Logone Floodplain at the beginning of the hot dry season (Moritz et al. 2014). We have found evidence for an ideal free like distribution at two different times in the hot dry season (February and May) and in two different seasonal grazing areas (Logone Floodplain and Lake Maga area). These findings offer further support for the hypothesis that the pastoral system is a self-organizing management system in which mobile pastoralists distribute themselves effectively over the available common-pool grazing resources in a situation of open access (Moritz et al. 2013b).

\section{Ideal Free Distribution Between Seasonal Grazing Areas}

Our theoretical model would predict that mobile pastoralists not only distribute themselves within seasonal grazing areas but also between seasonal grazing areas in an IFD. While we did find strong evidence for the predictions within the two seasonal grazing areas of the Logone Floodplain and the Lake Maga area, we did not find any evidence for such a distribution between the two areas. While the NDVI values and the number of cattle in the Lake Maga area are consistently higher than in the Logone Floodplain, the ratios do not match as predicted by the IFD. There may be several reasons why we did not find an IFD between seasonal grazing areas, aside from the fact that we have only 3 yr of data for only two areas; Yaayre Woylare and Mayo Dore are two other dry season grazing areas that pastoralists in our study area use.

First, the month of May is both the end of the dry season as well as the beginning of the transition season. At the end of the hot dry season NDVI values are low everywhere. However, in some years May marks the beginning of the transition season as the first rains fall, and there is fresh forage. This means that mobile pastoralists may already be on their way to their rainy season grazing areas and that the distribution of pastoralists does not necessarily reflect the current state of the dry season grazing areas. For example, some pastoralists use seasonal grazing areas for transit only to get from one area to another (e.g., pastoralists moving from Yaayre Woylare through the Yaayre and Ndiyam Shinwa to Fombina) (Fig. 1).

Second, travel costs between the two seasonal grazing areas of the Logone Floodplain and the Lake Maga area are not negligible. Pastoralists have to weigh the costs and benefits of traveling. This is particular the case at the end of the dry season when animals have already lost considerable weight and are more susceptible to diseases. Moving over larger distances has greater consequences for animal health and well-being than similar moves at the end of the rainy season when animals are in much better condition. Because cattle conditions are at their worst at this time, it may make more sense not to travel over long distances for pastures that are marginally better. The distribution of the pastoralists may thus reflect an earlier distribution of resources in which pastoralists used camp zones that were initially more productive.

Third, there is considerable regularity in the transhumance patterns at population level, which is the result of the habitual movements of the herds in which cattle develop woowaande (habitude) or preference for the pastures and campsites they visit annually and where they were born and/or gave birth. For example, some cattle prefer the pastures of the Logone Floodplain, whereas others prefer those of the Lake Maga area. These preferences develop over time as cattle are trained to graze specific species on specific pastures (Schareika 2003; Krätli 2008; Krätli and Schareika 2010). Because of habitude pastoralists are reluctant to change their habitual orbit because of the additional costs of animals that are not thriving on new pastures. It takes a year (or more) for cattle to learn to graze and thrive on new pastures.

In addition to habitude of the animals, herders and herd managers also have preferences for specific seasonal grazing areas. For example, many herders, who take the animals to pasture during the day, prefer the Lake Maga area because the work is less arduous; herds travel less and it is much cooler as animals practically graze in the lake, whereas herd managers, the ones managing the herds, prefer the Logone Floodplain

Table 6. Comparing cattle numbers and NDVI values between Logone Floodplain (LF) and Lake Maga area (LM), $2010-2012$.

\begin{tabular}{|c|c|c|c|c|c|c|c|c|}
\hline & \multicolumn{2}{|c|}{ No. of cattle } & \multicolumn{2}{|c|}{ Percentage of cattle } & \multicolumn{2}{|c|}{ Total NDVI value $^{1}$} & \multicolumn{2}{|c|}{ Percentage NDVI value } \\
\hline & LF & LM & LF & LM & LF & LM & LF & LM \\
\hline 2010 & 32310 & 37905 & 46 & 54 & 26.059 & 42.67 & 38 & 62 \\
\hline 2012 & 23480 & 26995 & 47 & 53 & 31.474 & 48.301 & 39 & 61 \\
\hline
\end{tabular}

${ }^{1}$ Total NDVI value refers to the NDVI values of all the camp zone buffers in the area. 
because they consider it much better for the condition of the animals. The habitudes or preferences of humans and animals for particular seasonal grazing areas introduces a certain lag to the system in that pastoralists are reluctant to make radical changes in their transhumance orbit, especially at the end of the dry season when animals are in their worst condition.

\section{Process of Self-Organization}

The main goal of this paper is to provide additional evidence that the pastoral system is a self-organizing system in which pastoralists distribute themselves over the available resources in an IFD, and that the pastoral system in the Logone Floodplain is not unique. One of the questions that remains is how do pastoralists distribute themselves over available resources and achieve an IFD, or, how does this self-organizing system work? We are examining this question in a separate article in which we use agent-based modeling to examine whether the key conditions that we have identified-open access to commonpool grazing resources, freedom of movement within and between seasonal grazing areas (within and across nations), independent and autonomous decision making, habitual movements, and complete information about the distribution and condition of grazing resources (and other pastoralists) (Moritz et al. 2013b)—are indeed critical for this selforganizing system.

\section{IMPLICATIONS}

The current consensus is that open access to common-pool grazing resources will result in a tragedy of the commons (Hardin 1968). This assumption is also shared by critics of Hardin's thesis (Ostrom 1990; Homewood 2008; Galvin 2009). However, our studies have shown that this is not the case in the Far North Region of Cameroon (Moritz et al. 2013b, 2014), and we have argued that this self-organizing management system of open access to common-pool grazing resources is common across West Africa (Stenning 1957; Frantz 1986; Horowitz 1986; Swallow 1990; Berge 2001). Identifying the key conditions for the success of this self-organizing system is critical for pastoral development in sub-Saharan Africa, in particular the development and implementation of rural and pastoral codes. The key conditions that we have identified are open access to common-pool grazing resources, freedom of movement within and between seasonal grazing areas (within and across nations), independent and autonomous decision making, and complete information about the distribution and condition of grazing resources (and other pastoralists) (Moritz et al. 2013b). Open access and freedom of movement within and between seasonal grazing areas need to be supported by institutions at multiple levels because mobile pastoralism transcends multiple institutional scales. Rangeland governance should be integrated at local, regional, national, and international scales. The Lake Chad Basin Committee (LCBC), for example, governs and supports livestock mobility at national and international levels within the Chad Basin (Moritz et al. 2013a). The challenge will be to find the right balance to solve the "paradox of pastoral land tenure" (Fernández-Giménez 2002), which is that pastoralists need secure access to pasture and water, but also flexibility in resource use, i.e., the ability to move elsewhere because of spatiotemporal variation in resource availability (Niamir-Fuller 1999; Turner 1999). Pastoralists' rights to common-pool grazing resources should be protected at the highest institutional levels, but there should be enough flexibility at the local levels for herders, farmers, and authorities to find efficient and low-cost solutions for competing land uses without threatening pastoral mobility at the larger spatial scales.

\section{ACKNOWLEDGMENTS}

We would like to thank the pastoralists in the Far North Region of Cameroon for participating in this study. We also want to thank Centre d'Appui à la Recherche et au Pastoralisme (CARPA) for research support in the field. We would like to thank the Ministry of Scientific Research and Innovation (MINRESI), the Wildlife College in Garoua, and the Higher Institute of the Sahel (ISS) at the University of Maroua for granting research permission and research affiliation (2008-2012). Yu-Jen Chen made the figures and maps.

\section{LITERATURE CITED}

AnYamba, A., AND C. J. Tucker. 2005. Analysis of Sahelian vegetation dynamics using NOAA-AVHRR NDVI data from 1981-2003. Journal of Arid Environments 63:596-614.

Bassett, T. J., and M. D. TuRner. 2007. Sudden shift or migratory drift? Fulbe herd movements to the Sudano-Guinean region of West Africa. Human Ecology 35:33-49.

Behnke, R., G. Davidson, A. Jabbar, and M. Coughenour. 2008. Human and natural factors that influence livestock distribution and rangeland desertification in Turkmenistan. In: R. Behnke [ED.]. NATO science for peace and security series. Dordrecht, the Netherlands: Springer. p. 141-170.

Behnke, R. H., M. E. Fernandez-Gimenez, M. D. Turner, and F. Stammler. 2011. Pastoral migration: mobile systems of livestock husbandry. In: E. J. Milner-Gulland, J. M. Fryxell, and A. R. E. Sinclair [EDS.]. Animal migration: a synthesis. Oxford, UK: Oxford University Press. p. 144-171.

BerGE, G. 2001. Tuareg notions of space and place in Northern Mali. In: T. A. Benjaminsen and C. Lund [EDS.]. Politics, property and production in the West African Sahel: understanding natural resource management. Uppsala, Sweden: Nordiska Afrikainstitutet. p. 182-207.

Boutrals, J. 1996. Hautes terres d'élevage au Cameroun. Vols. 1-3. Collection études et thèses. Paris: ORSTOM Éditions.

ButT, B. 2009. Seasonal space-time dynamics of cattle behavior and mobility among Maasai pastoralists in semi-arid Kenya. Journal of Arid Environments 74:403413.

Butr, B. 2010. Pastoral resource access and utilization: quantifying the spatial and temporal relationships between livestock mobility, density and biomass availability in southern Kenya. Land Degradation and Development 21:520-539.

Coughenour, M., R. Behnke, J. Lomas, and K. Price. 2008. Forage distributions, range condition, and the importance of pastoral movement in Central Asia-a remote sensing study. In: R. Behnke [ED.]. NATO science for peace and security series. Dordrecht, the Netherlands: Springer. p. 45-80.

Delclaux, F., C. Seignobos, G. Liénou, and P. Genthon. 2010. Water and people in the Yaéré floodplain (North Cameroon). In: M. A. Álvarez [ED.]. Floodplains: physical geography, ecology and societal interactions. Hauppauge, NY, USA: Nova Publishers. p. 1-27.

Fernández-Giménez, M. E. 2002. Spatial and social boundaries and the paradox of pastoral land tenure: a case study from postsocialist Mongolia. Human Ecology 30:49-79.

Frantz, C. 1986. Fulani continuity and change under five flags. In: M. Adamu and A. H. M. Kirk-Greene [EDS.]. Pastoralists of the West African savanna. Manchester, UK: Manchester University Press. p. 16-39. 
Fretwell, S. D., AND J. H. J. Lucas. 1969. On territorial behavior and other factors influencing habitat distribution in birds. Acta Biotheoretica 19:16-36.

Galvin, K. A. 2009. Transitions: pastoralists living with change. Annual Review of Anthropology 38:185-198.

Gordon, D. 2010. Ant encounters: interaction networks and colony behavior. Princeton, NJ, USA: Princeton University Press.

Hamilton, I. M. 2010. Foraging theory. In: D. Westneat and C. Fox [eds.]. Evolutionary behavioral ecology. Oxford, UK: Oxford University Press. p. 177-193.

HardIN, G. 1968. The tragedy of the commons. Science 162:1243-1248.

Homew0od, K. 2008. Ecology of African pastoralist societies. Oxford, UK: James Currey.

Horowitz, M. M. 1986. Ideology, policy, and praxis in pastoral livestock development. In: M. M. Horowitz and T. M. Painter [EDs.]. Anthropology and rural development in West Africa. Boulder, CO, USA: Westview Press. p. 251-272.

Jung, H. C., D. Alsdorf, M. Moritz, H. Lee, and S. Vassolo. 2011. Analysis of the relationship between flooding area and water height in the Logone floodplain. Physics and Chemistry of the Earth 36:232-240.

Kennedy, M., And R. D. Gray. 1993. Can ecological theory predict the distribution of foraging animals? A critical analysis of experiments on the ideal free distribution. Oikos 68:158-166.

Kennett, D. J., A. Anderson, and B. Winterhalder. 2006. The ideal free distribution, food production, and the colonization of Oceania. In: D. J. Kennett and B. Winterhalder [EDS.]. Behavioral ecology and the transition to agriculture. Berkeley, CA, USA: University of California Press. p. 265-288.

KRÄTLL, S. 2008. Cattle breeding, complexity and mobility in a structurally unpredictable environment: the WoDaaBe herders of Niger. Nomadic Peoples 12:11-41.

KrätLI, S., AND N. SCHAREIKA. 2010. Living off uncertainty: the intelligent animal production of dryland pastoralists. European Journal of Development Research 22:605-622.

Lansing, J. S. 2006. Perfect order: recognizing complexity in Bali. Princeton, NJ, USA: Princeton University Press.

Lillesand, T. M., R. W. Kiefer, and J. W. Chipman. 2007. Remote sensing and image interpretation. Malden, MA, USA: Wiley.

MItCHeLL, M. 2009. Complexity: a guided tour. Oxford, UK: Oxford University Press.

Moritz, M., L. B. Catherine, A. K. Drent, S. Kari, A. Mouhaman, and P. Scholte. 2013 a. Rangeland governance in an open system: protecting transhumance corridors in the far north region of Cameroon. Pastoralism: Research, Policy and Practice 3:26.

Moritz, M., Z. Galehouse, Q. Hao, and R. Garabed. 2012. Can one animal represent an entire herd? modeling pastoral mobility using GPS/GIS technology. Human Ecology 40:623-630.
Moritz, M., I. M. Hamllon, Y.-J. Chen, and P. Scholte. 2014. Mobile pastoralists in the Logone Floodplain distribute themselves in an Ideal Free Distribution. Current Anthropology 55:115-122.

Moritz, M., And P. Scholte. 2011. Ethical predicaments: advocating security for mobile pastoralists in weak states. Anthropology Today 27:12-17.

Moritz, M., P. Scholte, I. M. Hamilton, and S. Kari. 2013b. Open access, open systems: pastoral management of common-pool resources in the Chad Basin. Human Ecology 41:351-365.

Moritz, M., E. Soma, P. Scholte, T. Juran, L. Taylor, S. Kari, and N. Xiao. 2010. An integrated approach to modeling grazing pressure in pastoral systems: the case of the Logone Floodplain (Cameroon). Human Ecology 38:775-789.

Niamir-Fuller, M. [ED.]. 1999. Managing mobility in African rangelands: the legitimization of transhumance. London, UK: Intermediate Technology.

Ostrom, E. 1990. Governing the commons: the evolution of institutions for collective action. Cambridge, UK: Cambridge University Press.

SchareIKA, N. 2003. Know to move, move to know: ecological knowledge and herd movement strategies among the Wodaabe of Southeastern Niger. Rome, Italy: FAO Inter-Departmental Working Group on Biological Diversity for Food and Agriculture.

Scholte, P. 2005. Floodplain rehabilitation and the future of conservation and development: Adaptive management of success in Waza-Logone, Cameroon [dissertation]. Leiden, the Netherlands: Leiden University. 344 p.

Scholte, P. 2007. Maximum flood depth characterises above-ground biomass in African shallowly flooded grasslands. Journal of Tropical Ecology 23:63-72.

Scholte, P., S. Kari, M. Moritz, and H. Prins. 2006. Pastoralist responses to floodplain rehabilitation in northern Cameroon. Human Ecology 34:27-51.

Selgnobos, C., and O. Iyébi-Mandjek [eds.]. 2000. Atlas de la province Extrême-Nord Cameroun. Paris: IRD \& MINREST.

StenNing, D. J. 1957. Transhumance, migratory drift, migration; patterns of pastoral Fulani nomadism. Journal of the Royal Anthropological Institute of Great Britain and Ireland 87:57-73.

SutheRLAND, W. J. 1996. From individual behaviour to population ecology. Oxford, UK: Oxford University Press.

Swallow, B. M. 1990. Strategies and tenure in African livestock development. LTC paper no. 140. Madison, WI, USA: Land Tenure Center, University of Wisconsin.

TURNER, M. D. 1999. The role of social networks, indefinite boundaries and political bargaining in maintaining the ecological and economic resiliency of the transhumance systems of Sudano-Sahelian West Africa. In: M. Niamir-Fuller [ED.]. Managing mobility in African rangelands. London: IT Publications. p. 97123.

Winterhalder, B., D. J. Kennett, M. N. Grote, and J. Bartruff. 2010. Ideal free settlement of California's Northern Channel Islands. Journal of Anthropological Archaeology 29:469-490. 